DOI https://doi.org/10.30525/978-9934-26-148-0-46

\title{
ПРАВОВЕ РЕГУЛЮВАННЯ БЕЗПЕКИ СУДНОПЛАСТВА: ВИМОГИ ДО МІНІМАЛЬНОГО СКЛАДУ ЕКІПАЖУ МОРСЬКИХ СУДЕН
}

\author{
Костиря О. В. \\ кандидат юридичних наук, дочент кафедри морського права \\ Національного університету «Одеська морська академія»
}

Іванова А. В.

кандидат юридичних наук, дочент кафедри морського права Національного університету «Одеська морська академія» м. Одеса, Україна

У поняття «безпека на морі» входить великий комплекс заходів. Єдині норми проектування судна, критерії оцінки його технічних $\mathrm{i}$ економічних характеристик, суднове обладнання, правила руху в морі, укомплектованість екіпажом - далеко не повний перелік питань, від правильного рішення яких залежить збереження судна, людей і вантажу $[1$, c. 5$]$.

Актуальність теми правового регулювання встановлення мінімального складу екіпажів морських суден полягає в тому, що однією 3 поширених причин нещасних випадків на водному транспорті $\epsilon$ недостатня кількість членів екіпажу під час рейсу. Поступове скорочення чисельності екіпажів суден призводить до зростання відповідальності та ускладнення функцій, виконуваних судновими спеціалістами, що своєю чергою призводить до накопичення втоми працівників [2, с. 79].

На жаль, сьогодні бракує системних досліджень з питання правого регулювання встановлення мінімального складу екіпажів морських суден. Окремі аспекти цього питання у своїх роботах розглядали Орлова Н., Топалов В.П., Торський В.Г., Позолотін Л.А. та інші.

Вимоги Міжнародної морської організації щодо мінімального складу екіпажу морських суден відображені в Міжнародній конвенції з охорони людського життя на морі та в ряді резолюцій.

Так, на 73 сесії Комітету безпеки на морі Міжнародна морська організація в грудні 2000 року прийняла новий текст глави V Міжнародної конвенції з охорони людського життя на морі (СОЛАС-74). Правило 14 глави V конвенції СОЛАС -74 вимагає, щоб кожне судно, 
яке здійснює міжнародні рейси, було укомплектовано безпечним екіпажом 3 точки зору охорони людського життя на морі й мало Свідоцтво про мінімальний безпечний склад екіпажу, видане урядом держави, під прапором якої судно має право плавання [3].

Генеральна асамблея Міжнародної морської організації прийняла резолюцію А. 890 - «Принципи укомплектування безпечного складу екіпажів суден», яка покладає на Адміністрацію держави прапора судна відповідальність за встановлення мінімального безпечного складу екіпажу для кожного судна під своїм прапором, а також за видачу суднам документа про мінімальний безпечний склад екіпажу «Minimum Safe Manning Certificate» [4].

Міжнародна конвенція 2006 року «Про працю в морському судноплавстві» визначає, що мінімальний склад екіпажу повинен забезпечувати при будь-яких умовах експлуатації судна безпеку i охорону судна і його персоналу [5].

3 метою забезпечення безпеки мореплавства та відповідно до статті 35 Кодексу торговельного мореплавства України на кожне судно, яке має право плавання під прапором України, повинно видаватися Свідоцтво про мінімальний склад екіпажу.

Також, згідно зі ст. 50 КТМ України, мінімальний склад екіпажу, при якому допускається вихід судна в море, встановлюється центральним органом виконавчої влади, що забезпечує формування державної політики у сфері безпеки мореплавства суден флоту рибного господарства, залежно від типу судна, району плавання, а також його призначення.

У наказі Міністерства інфраструктури України «Про затвердження Порядку визначення мінімального складу екіпажу судна» від 10.11.2014 № 575, зі змінами, внесеними згідно з Наказами Міністерства інфраструктури № 158 від 24.04. 2016 та № 399 від 16.07.2020 років, визначаються принципи та критерії, що враховуються під час визначення мінімального складу екіпажу.

При визначенні мінімального складу екіпажу повинні бути враховані такі принципи:

- здатність нести безпечну ходову навігаційну вахту, машинну та радіовахту і вести загальний контроль за судном, механізмами та обладнанням;

- можливість безпечно здійснювати швартові операції;

- здатність виконувати дії щодо попередження спричиненню шкоди навколишньому природному середовищу;

- забезпечення належного медико-санітарного догляду на судні;

- забезпечення безпеки перевезення пасажирів та вантажів; 
- здатність забезпечувати перевірку та підтримку конструкційної цілісності судна;

- забезпечення експлуатації судна відповідно до Плану охорони судна;

- здатність та можливість експлуатувати всі пристрої, що забезпечують водонепроникність, підтримання їх у ефективному стані, використання компетентної аварійної партії з боротьби за живучість судна;

- здатність та можливість експлуатувати суднове протипожежне та аварійне обладнання, рятувальні засоби, виконуючи всі необхідні регламентні роботи з їх технічного обслуговування та ремонту;

- здатність експлуатувати та підтримувати в належному стані головне рушійне устаткування та допоміжні механізми.

Також необхідно врахувати ті суднові функції, які застосовуються для кожного окремого судна з урахуванням типу (призначення) судна, району плавання тощо.

Під час визначення мінімального складу екіпажу необхідно враховувати такі критерії експлуатації та характеристики судна:

- вік судна;

- тривалість, характер рейсів і район плавання;

- кількість, потужність, ступінь автоматизації та тип головних енергетичних установок і допоміжних механізмів;

- валову місткість судна;

- безпеку судна під час операцій в порту;

- конструкцію, автономність та технічне обладнання судна;

- тип вантажу або кількість пасажирів, що перевозяться [6].

Однак, незважаючи на вимоги Міжнародної морської організації, Міжнародної організації праці та національних законодавств Держав прапору по визначенню мінімального складу екіпажу, існує необхідність посилення контролю над суднами 3 боку Держави порту, яка обумовлюється наступними обставинами - це старіння світового флоту, скорочення екіпажів суден, ускладнення технічного обладнання та технології перевезень. Правило 4 глави XI - I СОЛАС-74 і Резолюція IMO А. 1138(31) «Процедури контролю суден державою порту» 2017 року розглядають наявність на судні «Документа про мінімальний безпечний склад екіпажу» як доказ того, що дане судно безпечно щодо якісного складу і структури екіпажу [7].

Таким чином, безпечний склад екіпажу залежить від кількості кваліфікованих і досвідчених моряків, необхідних для забезпечення безпеки судна, екіпажу і пасажирів, збереження вантажу і майна, а також захисту морського середовища. 
Міжнародна морська організація та Міжнародна організація праці приділяють велику увагу до мінімального складу екіпажу морських суден, як одному з найважливіших аспектів безпеки мореплавства.

Усі судна, які мають право плавання під прапором України, згідно 3 чинним законодавством, повинні бути сертифіковані та мати на борту Свідоцтво про мінімальний склад екіпажу.

\section{Література:}

1. В.П. Топалов, В.Г. Торський. Конвенція СОЛАС - 74. Основні положення та коментарі. Одеса: Астропринт, 2002. 288 с.

2. Орлова н. Особливості правового регулювання охорони праці на водному транспорті. Підприємництво, господарство $i$ право. 2020. № 6. C. 79 - 84. URL: http://pgp-journal.kiev.ua/archive/2020/6/16.pdf (дата звернення:19.09.2021).

3. Міжнародна конвенція 3 охорони людського життя на морі 1974 p. URL: https://zakon.rada.gov.ua/laws/show/995_251\#Text (дата звернення: 19.09.2021).

4. Резолюція А.890 (21) Принципи визначення стану безпеки складу екіпажу (Прийнята 25 листопада 1999 роки) URL: http://rise.odessa.ua/ texts/A890_21_99.php3 (дата звернення: 19.09.2021).

5. Конвенція Міжнародної організації праці 2006 року про працю в морському судноплавстві URL: https://zakon.rada.gov.ua/laws/show/ 993 519\#Text (дата звернення: 19.09.2021).

6. Наказ Міністерства інфраструктури України «Про затвердження Порядку визначення мінімального складу екіпажу судна «від 10.11.2014 № 575 URL: https://zakon.rada.gov.ua/laws/show/z1507-14\#Text (дата звернення: 19.09.2021).

7. Resolution A.1138(31) Adopted on 4 December 20 December 2019 (Agenda item 10) Procedures for port state control, 2019 URL: https://wwwcdn.imo.org/localresources/en/OurWork/IIIS/Documents/ A\%2031-Res.1138\%20-\%20PROCEDURES\%20FOR\%20PORT\%20 STATE\%20CONTROL,\%202019.pdf (дата звернення: 19.09.2021). 